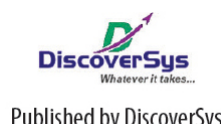

Published by DiscoverSys

\section{The roles of private practice midwives in Prevention of Mother-To-Child Transmission Program (PMTCT) in Bali Province, Indonesia}

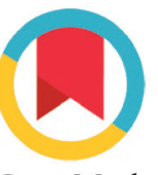

CrossMark

\author{
I Ketut Dwipayana, ${ }^{1 *}$ Pande Putu Januraga, ${ }^{2}$ Ni Made Dian Kurniasari ${ }^{2}$
}

\section{ABSTRACT}

Background and purpose: Mother-to-child transmission of HIV has been one of the problems in HIV prevention. In Indonesia, private practice midwives (PPM) play an important role in maternal and child health services. The roles of PPM in HIV vertical transmission prevention through PMTCT have not yet clearly understood. This research aims to analyse the roles of PPM in Bali Province in the PMTCT program as well as the PPM's characteristics, knowledge, and attitudes about the program.

Methods: This study was a descriptive cross-sectional survey, conducted from March to May 2020. The study population was PPM in Bali Province. The samples obtained were 404 out of a total of 1,736 PPM (23\% response rate). The variables studied included socio-demographic characteristics, services and resources characteristics, knowledge, attitudes, and the role of PPM in four PMTCT prongs. Data was collected via self-filled online questionnaires distributed through Indonesian Midwives Associations branches in every district/city in Bali Province. Data were analysed descriptively and differences in roles in PMTCT were analysed using the chi-square test.

Results: Of the 404 PPM, 66.1\% served childbirth (deliveries), 25.4\% had served HIV-positive women, and $18.3 \%$ had served HIV-positive pregnant women. As many as $95.5 \%$ of PPM played a good role in prong 1, and $99.0 \%$ of PPM, who had served HIV positive patients, played a good role in prong 2, 3 and 4. Statistically significant determinants for good implementation of prong 1 of PMTCT by the PPM were indicated by ownership or access to PMTCT information media ( $p=0.026$ ), experience of serving HIV positive women $(p<0.00)$, and having served higher number of PMTCT patients $(p=0.019)$.

Conclusion: The PPM in Bali Province has played a good role in PMTCT, with a significant difference for good PMTCT implementation in prong 1 determined by the availability of information media, a history of serving HIV-positive women, and the number of PMTCT patients who have been served.

Keywords: Private practice midwives, PMTCT, Bali

Cite this Article: Dwipayana. I.K., Januraga, P.P., Kurniasari, N.M.D. 2020. The roles of private practice midwives in Prevention of MotherTo-Child Transmission Program (PMTCT) in Bali Province, Indonesia. Public Health and Preventive Medicine Archive 8(2): 99-105. DOI: 10.15562/phpma.v8i2.303

1Petang 1 Public Health

Center

${ }^{2}$ Department of Public Health and Preventive Medicine, Faculty of Medicine, Udayana University

*Correspondence to: I Ketut Dwipayana; Petang 1 Public Health Center; drdwipayana@gmail.com

\section{INTRODUCTION}

Human Immunodeficiency Virus (HIV) infection has been a global health problem which affected around 37.9 million people worldwide. ${ }^{1}$ The number of new infections reached 1.7 million and 770,000 people had died from HIV-related diseases. ${ }^{2}$ The rate of mother-to-child transmission of HIV accounts for $10 \%$ of all HIV transmission in general and in 2016 there were approximately 3.1 million children infected with HIV globally. ${ }^{3}$ More than $90 \%$ of HIV infection in infants is obtained from mothers who are HIV positive. The transmission can occur during pregnancy, childbirth and breastfeeding. ${ }^{4}$ The average rate of mother-to-child HIV transmission in the world without intervention is between $15-45 \% .^{5}$

The number of HIV cases has also been increasing overtime, with the latest cumulative number reached 511,955 cases in 2020 in Indonesia. Likewise, the number of mothers to child transmission is quite large. In 2016, the vertical HIV transmission rate from mother to baby in the first 6 weeks after giving birth was $26.6 \%$, which was the highest rate in the world that year. ${ }^{6}$ The number of HIV/AIDS patients in Bali Province between 19872018 based on cumulative data reached 20,471 and ranked the fifth in Indonesia. ${ }^{7}$ Data from the Bali Province AIDS Commission shows that the number of children infected with HIV/AIDS in Bali is 3.7\% in 2019, which is quite high. Transmission mostly occurs when the child is in the womb. Meanwhile, the number of pregnant women who were HIV positive has reached 209 people with 195 people regularly receiving ART. ${ }^{8}$

The Indonesian government has implemented the Prevention of Mother-to-Child Transmission (PMTCT) program since 2005 to curb vertical transmission of HIV from mother to child. This program has been implemented in all public and private health facilities aimed at all women of reproductive age. Health workers involved ranging from medical specialist, general practitioners, 
midwives, and other health officers who provide supporting examinations. ${ }^{9} \quad$ Private practice midwives (PPM) have a very important role in implementing the PMTCT program for pregnant women and women of reproductive age, because nationally, most pregnant women perform their antenatal care (ANC) at PPM. ${ }^{10}$ With an estimated of 5.3 million pregnancies each year, more than $52 \%$ of pregnant women in Indonesia perform ANC at PPM, and the rest use other health facilities such as the public health centres (PHCs) (16.6\%), integrated community health post (10\%), village health post (6\%), obstetrics/general practitioner clinic (4.3\%), hospital (10\%), and others (0.6\%). ${ }^{11}$ The PMTCT program is consisting of four prongs or activity units, namely prevention of HIV transmission to women of reproductive age (prong 1), prevention of unplanned pregnancies in HIV positive women (prong 2), prevention of HIV transmission from mothers to their infants (prong 3), and provision of psychological, social support and care for HIV positive mothers and their children as well as their families (prong 4). The PPM is expected to provide the four prongs of this PMTCT program. ${ }^{9}$

In Bali, more than half $(63.8 \%)$ of all pregnant women had tested for HIV in 2017. ${ }^{8}$ However, this achievement was mostly from pregnant women who had their pregnancy checked at the public health facilities, which was $71.7 \%$. The attainment of HIV test in PPM was only $55.9 \%$ or is still lower than that of PMTCT at the PHCs or hospitals (80\%). ${ }^{10}$

Previous research by Wulandari et.al (2019) found that of all pregnant women who were referred by PPM for HIV testing, only 50\% actually came to facilities that had HIV testing facilities. ${ }^{10}$ Another study in Denpasar City found that the length of work, training and motivation of the PPM determine their role in implementing the PMTCT program. ${ }^{12}$ In addition, a study also examined the role of health workers in the PMTCT program in 2018 but not specifically examining PMTCT among PPM. ${ }^{13}$ Against the backdrop of the importance of the PPM role in ANC and hiatus of research on the role of PPM in the PMTCT program implementation in the prongs, this study aimed to explore the role of PPM in implementing the PMTCT program in Bali Province.

\section{METHODS}

The study was a descriptive cross-sectional survey, carried out to all PPM in Bali Province from March to May 2020. The population was all PPM in Bali Province, with a total number of 1,736 PPM consisting of 387 PPM from Denpasar City, 338 from Karangasem District, 173 from Gianyar, 163 from Buleleng, 123 from Bangli, 100 from
Tabanan, 86 from Jembrana, 60 from Badung, and 45 from Klungkung. The minimum sample size for this study was calculated using the Slovin formula, resulted in 325 midwives (margin of error of 0.05 ). The inclusion criteria in this study were all PPM in Bali Province who had practiced for at least six months, had an email address and/or whatsapp messenger and were willing to participate in this research. The study used total sampling and 440 PPM participated in the study (23\% response rate). Of the 404 PPM who provided their responses, all met the established inclusion criteria.

This study used the role of health workers approach, including midwives adapted from the B. Rowan, J. Robinson, A. Granato et.al and explored variables related to the characteristics, knowledge, attitudes and role of PPM in implementing the PMTCT prongs. ${ }^{13}$ The characteristics of PPM explored include the district where they live in Bali, age (in years), education level and other occupations other than midwives in PPM (civil servants or not). In addition, the PPM services and resources characteristics explored include areas of practice (rural, suburban, or urban), length of practice (1-5 years, 6-10 years, and $>10$ years), number of PMTCT patients who had been served (none, 1-36, and $>36$ ), providing delivery assistance (yes and no), the average number of deliveries assisted per month (1-5 and >5), number of staff (alone, having 1 staff and has $>1$ staff), type of training (HIV training materials, HIV counselor training, PMTCT training, and HIV/PMTCT seminars), availability of budget for PMTCT (yes and no), availability of assistive tools (yes and no).

The PPM knowledge on PMTCT was measured by exploring their knowledge on the objectives and benefits of PMTCT, the obligation of PPM to implement PMTCT, the requirements for implementation and guidelines for implementing PMTCT. While, the attitude of PPM was measured by exploring their attitudes related to their enthusiasm, responses regarding the benefits and obligations of implementing PMTCT. The knowledge and attitude were categorized as "good" if they can answer $50 \%$ or more of all questions correctly, and "lacking" if they answer less than 50\% of the questions correctly.

The role of PPM was measured in four PMTCT prongs. Prong 1, namely the prevention of HIV transmission to women of reproductive age, was measured by exploring whether midwives provide HIV education, advise women of reproductive age who are at risk for testing, and provide psychological support to do HIV testing. Prong 2 to 4 were measured in midwives who had ever served HIV positive patients. Prong 2, namely the 
role of PPM in preventing unwanted pregnancy and pregnancy planning in HIV-infected women. It was measured by looking at whether midwives provide counselling to HIV-infected women to use contraception and provide contraception in their practice locations. Prong 3, namely the role of PPM in preventing HIV transmission from pregnant women with HIV to their babies. This prong was measured by looking at the ANC services implemented by PPM, whether the PPM refers patients to antiretroviral examinations and therapy if the results are positive, and delivery planning for HIV positive pregnant women. Prong 4, namely the role of PPM in providing psychosocial support for HIV-infected mothers. It was measured by looking whether PPM provides breastfeeding counselling for HIV positive babies, provides counselling to families of HIV positive patients, and provides psychosocial support as well as medical support and care for HIV positive mothers. Each role in the PMTC prong 2 to 4 was categorized as "good" if it carries out $50 \%$ or more of all the activities required in the prong, and "lacking" if it carries out less than half of the activities required in each prong.

Data was collected using a self-filled online questionnaire with a Google Forms application, the questionnaire link was sent to the Indonesian Midwives Association (IMA) Branch WhatsApp messenger group. Questionnaire was modified from

Table 1. Characteristics of PPM

\begin{tabular}{lcc}
\hline Characteritics (n=404) & $\mathbf{n}$ & \% \\
\hline Districts & & \\
Badung & 92 & 22.8 \\
Tabanan & 68 & 16.8 \\
Denpasar & 62 & 15.4 \\
Buleleng & 55 & 13.6 \\
Karangasem & 55 & 13.6 \\
Gianyar & 28 & 6.9 \\
Klungkung & 24 & 5.9 \\
Bangli & 12 & 3.0 \\
Jembrana & 8 & 2.0 \\
Age (years) & & \\
Min-max & $24-74$ & \\
Mean (SD) & $44(10)$ & \\
Median (IQR) & $45(13)$ & 33.4 \\
Age group (years) & & 58.9 \\
24-40 & 135 & 7.7 \\
41-56 & 238 & \\
>56 & 31 & 85.6 \\
Education level & & 11.9 \\
D3 (3yrs Diploma) & 346 & 2.5 \\
D4 (4yrs Diploma) & 48 & \\
S1/S2 (Bachelor/Magister) & 10 & 25.5 \\
Length of practice & & 21.5 \\
1-5 yrs & 103 & 53.0 \\
6-10 yrs & 87 & 45.0 \\
>10 yrs & 214 & \\
Other employments & & \\
Civil servants & 182 & \\
Non-civil servants & & \\
\hline & & \\
\hline
\end{tabular}

Assessment of PMTCT Services Questionnaire (The Elizabeth Glaser Pediatric Aids Foundation (EGPAF) $){ }^{14}$ Data were analysed descriptively to obtain an overview of the characteristics and role of PPM in PMTCT. Quality of PMTCT implementation was analysed based on characteristics, knowledge and attitudes using the chi-square test, with IBM SPSS statistic 20.

Ethical clearance was obtained from the Research Ethics Commission of the Faculty of Medicine, Udayana University no: 680/UN14.2.2.VII.14/ LT/2020. Informed consent was included in the questionnaire page and was approved by the respondents. All identities and research data were stored confidentially.

\section{RESULTS}

Of the 404 responses obtained, PPM who filled out the survey were spread across 9 districts/cities with the largest number coming from Badung District counted as much as $22.8 \%$ and the remaining $77.2 \%$ from other districts/cities in Bali. As many as 58.9\% of all PPM were aged $41-56$ years, $85.6 \%$ had a three years of Diploma (D3) education background, 53\% of PPM had practiced for more than 10 years and apart from being PPM, 55\% of respondents also worked as civil servant midwives at the PHCs. An overview of the distribution of respondents characteristics are presented in Table 1.

Table 2 shows that the PPM who filled out the questionnaire mostly practiced in rural areas (61.6\%), and those who provided delivery care in their private practice were $66.1 \%$, with the average number of deliveries performed is between 1-5 per month (74.2\%). Proportion of PPM who have ever provided delivery services to HIV positive mothers was $18.3 \%$. The number of patients served in relation to the PMTCT program in their practice was mostly less than 36 people $(71 \%)$. Most of PPM (77\%) have at least 1 person or more staff (assistant) in their practice. Almost all of PPM do not have a special budget to implement the PMTCT program (92.6\%). Less than half of the PPM (47\%) have provided media information in the form of brochures, leaflets or flipcharts about PMTCT in their practice places. In addition, only $47.2 \%$ of them who have attended any HIV/related or PMTCT training.

Almost all PPM have good knowledge and good attitude regarding PMTCT with the percentage of $90.8 \%$ and $97.0 \%$, respectively (Table 3 ). It can also be seen that $95.5 \%$ of the 404 PPM have played a good role in prong 1 of PMTCT which is preventing HIV transmission to women of reproductive age. For those who had ever provided care for HIV positive patients (103 PPM), 99.0\% of them also 
Table 2. PPM practice and resources characteristics

\begin{tabular}{|c|c|c|}
\hline Characteristics $(n=404)$ & $\mathbf{n}$ & $\%$ \\
\hline \multicolumn{3}{|l|}{ Area of practice } \\
\hline Rural & 249 & 61.6 \\
\hline Sub urban & 81 & 20.1 \\
\hline Urban & 74 & 18.3 \\
\hline \multicolumn{3}{|l|}{ Provide delivery care } \\
\hline Yes & 267 & 66.1 \\
\hline No & 137 & 33.9 \\
\hline \multicolumn{3}{|c|}{ Number of delivery per month $(n=267)$} \\
\hline $1-5$ & 198 & 74.2 \\
\hline$>5$ & 69 & 25.8 \\
\hline \multicolumn{3}{|c|}{ Had ever provided care for HIV $(+)$ women } \\
\hline Yes & 103 & 25.4 \\
\hline No & 301 & 74.6 \\
\hline \multicolumn{3}{|c|}{ Had ever provided care for HIV $(+)$ pregnant women } \\
\hline Yes & 74 & 18.3 \\
\hline No & 330 & 81.7 \\
\hline \multicolumn{3}{|l|}{ Number of PMTCT patient served } \\
\hline 0 & 95 & 23.5 \\
\hline $1-36$ & 192 & 47.5 \\
\hline$>36$ & 117 & 29.0 \\
\hline \multicolumn{3}{|l|}{ Resources } \\
\hline \multicolumn{3}{|l|}{ Number of staff } \\
\hline 0 & 93 & 23.0 \\
\hline 1 & 154 & 38.1 \\
\hline$>1$ & 157 & 38.9 \\
\hline \multicolumn{3}{|c|}{ Spesific budget allocated for PMTCT } \\
\hline Yes & 30 & 7.4 \\
\hline No & 374 & 92.6 \\
\hline \multicolumn{3}{|c|}{ Provide medias for PMTCT education } \\
\hline Yes & 190 & 47.0 \\
\hline No & 214 & 53.0 \\
\hline \multicolumn{3}{|c|}{ Had ever enrolled in any HIV/PMTCT training $(n=400)$} \\
\hline Yes & 189 & 47.2 \\
\hline No & 211 & 52.8 \\
\hline \multicolumn{3}{|c|}{ Type of HIV/PMTCT training $(n=189)^{*}$} \\
\hline HIV education & 47 & 24.9 \\
\hline HIV counselling & 60 & 31.4 \\
\hline PMTCT or PPIA training & 69 & 36.5 \\
\hline HIV or PPIA seminars & 95 & 50.3 \\
\hline
\end{tabular}

${ }^{*}$ Answers can be more than one

Table 3. Knowledge, attitude and role of PPM in the 4 prongs of PMTCT

\begin{tabular}{|c|c|c|}
\hline $\begin{array}{ll}\text { Variable } \\
\end{array}$ & $\mathbf{n}$ & $\%$ \\
\hline \multicolumn{3}{|l|}{ Knowledge level $(n=404)$} \\
\hline Good & 367 & 90.8 \\
\hline Lacking & 37 & 9.2 \\
\hline \multicolumn{3}{|c|}{ Attitude regarding PMTCT $(\mathrm{n}=404)$} \\
\hline Good & 392 & 97.0 \\
\hline Lacking & 12 & 3.0 \\
\hline \multicolumn{3}{|l|}{ Role in prong $1(n=404)$} \\
\hline Good & 386 & 95.5 \\
\hline Lacking & 18 & 4.5 \\
\hline \multicolumn{3}{|l|}{ Role in prong $2(n=404)$} \\
\hline Good & 101 & 25.0 \\
\hline Lacking & 303 & 75.0 \\
\hline \multicolumn{3}{|l|}{ Role in prong $3(n=404)$} \\
\hline Good & 102 & 25.2 \\
\hline Lacking & 302 & 74.8 \\
\hline \multicolumn{3}{|l|}{ Role in prong $4(n=404)$} \\
\hline Good & 98 & 24.3 \\
\hline Lacking & 306 & 75.7 \\
\hline \multicolumn{3}{|l|}{ Role in prong $2,3,4(n=103)^{*}$} \\
\hline Good & 102 & 99.0 \\
\hline Lacking & 1 & 1.0 \\
\hline
\end{tabular}

${ }^{\star}$ Only PPM who had ever provided care for HIV positive patients performed a good role in prong 2,3 and 4 of the PMTCT.

From Table 3, we can also see that if the roles of prong 1 and prong 2,3,4 are assessed separately only for those who served the service for these prongs, then the role of PPM is largely good. However, these roles are assessed for all including for those who never served HIV-positive female patients, then only about a quarter of all respondents $(25 \%)$ have a good overall role for prongs 2, 3 and 4 in all 404 PPM.

Further, the distribution of the PPM role in the PMTCT program was analysed for their role in prong 1, namely in the prevention of HIV transmission to women of reproductive age, since only prong 1 that has been practiced by the majority of the PPM. This were differentiated based on the PPM characteristics, characteristics of their practice and resources, as well as their knowledge and attitudes regarding PMTCT (Table 4).

From Table 4, we can see that the availability of information media $(\mathrm{p}=0.026)$, the experience of providing care for HIV positive patients $(\mathrm{p}<0.000)$, and the number of PMTCT patients who had been served ( $\mathrm{p}=0.019)$ were significantly associated with good practice of prong 1 in PMTCT among the surveyed PPM.

While from Table 5, it can be seen that the level of knowledge and attitude of the PPM regarding PMTCT were not significantly associated with their PMTCT program implementation for prong $1(\mathrm{p}>0.05)$.

\section{DISCUSSION}

Our research shows that the role of PPM in Bali Province in PMTCT program is mostly good. Almost all aspects of the PMTCT prongs according to the PMTCT guidelines issued by the Ministry of Health ${ }^{9}$ have been implemented by the PPM. Especially for prong 1, the PPM has been providing education about HIV to women of reproductive age on a regular basis, advising women of reproductive age who are at risk for testing, and providing psychological support to get tested for HIV.

Of all respondents, only about a quarter have served HIV positive patients. Among the PPM, it can be seen that they have implemented prong 2 in the form of providing counselling to HIV-infected women to use contraceptives and providing contraception in their private practice places. Respondents who have served HIV positive women also played a role in prong 3 by implementing ANC services, referring patients for HIV testing and ARV therapy if the results were positive, and delivery planning for HIV positive pregnant women. In prong 4, PPM play a role in providing breastfeeding 
Table 4. Role of PPM in prong 1 based on their characteristics

\begin{tabular}{|c|c|c|c|c|}
\hline \multirow{2}{*}{ Variable } & \multicolumn{2}{|c|}{$\begin{array}{c}\text { Role of PPM in PMTCT } \\
\text { prong } 1\end{array}$} & \multirow{2}{*}{$\begin{array}{l}\text { Total } \\
\text { n (\%) }\end{array}$} & \multirow{2}{*}{$\mathbf{p}$} \\
\hline & $\begin{array}{l}\text { Good } \\
\text { n (\%) }\end{array}$ & $\begin{array}{l}\text { Lacking } \\
\text { n (\%) }\end{array}$ & & \\
\hline \multicolumn{5}{|l|}{ Age group (years) } \\
\hline $20-39$ & $99(28.4)$ & $22(40.0)$ & $121(30.0)$ & 0.198 \\
\hline $40-59$ & $228(65.3)$ & $31(56.4)$ & $259(64.1)$ & \\
\hline$\geq 60$ & $22(6.3)$ & $2(3.6)$ & $24(5.9)$ & \\
\hline \multicolumn{5}{|l|}{ Districts } \\
\hline $\begin{array}{l}\text { Badung and } \\
\text { Denpasar }\end{array}$ & $138(39.5)$ & $16(29.1)$ & $154(38.1)$ & 0.132 \\
\hline Other districts & $211(60.5)$ & $39(70.9)$ & $250(61.9)$ & \\
\hline \multicolumn{5}{|l|}{ Other employments } \\
\hline Civil servant & $195(55.9)$ & $27(49.1)$ & $222(55.0)$ & 0.348 \\
\hline Non-civil servants & $154(44.1)$ & $28(50.9)$ & $182(45.0)$ & \\
\hline \multicolumn{5}{|l|}{ Length of practice (years) } \\
\hline $1-5$ & $95(24.6)$ & $8(44.4)$ & $103(25.5)$ & 0.203 \\
\hline $6-10$ & $84(21.8)$ & $3(16.7)$ & $87(21.5)$ & \\
\hline$>10$ & $207(53.6)$ & $7(38.9)$ & $214(53.0)$ & \\
\hline \multicolumn{5}{|l|}{ Education } \\
\hline D3 (3 yrs Diploma) & $296(48.8)$ & $48(87.3)$ & $344(85.1)$ & 0.310 \\
\hline D4 (4 yrs Diploma) & $41(11.7)$ & $7(12.7)$ & 48 (11.9) & \\
\hline S1/S2 (Bachelor/Magister) & $10(2.9)$ & $0(0.0)$ & $10(2.5)$ & \\
\hline \multicolumn{5}{|l|}{ Number of staff } \\
\hline 0 & $79(22.6)$ & $14(25.5)$ & $93(23.0)$ & 0.143 \\
\hline 1 & $128(36.7)$ & $26(47.3)$ & $154(38.1)$ & \\
\hline$>1$ & $142(40.7)$ & $15(27.3)$ & $157(38.9)$ & \\
\hline \multicolumn{5}{|l|}{ Provide delivery care } \\
\hline No & $129(33.4)$ & $6(33.3)$ & $135(33.4)$ & 0.912 \\
\hline Yes & $255(66.1)$ & $12(66.7)$ & $267(66.1)$ & \\
\hline \multicolumn{5}{|l|}{$\begin{array}{l}\text { Had ever enrolled in PMTCT } \\
\text { training }\end{array}$} \\
\hline No & $218(56.5)$ & $14(77.8)$ & $232(57.4)$ & 0.150 \\
\hline Yes & $163(42.2)$ & $4(22.4)$ & $167(41.3)$ & \\
\hline \multicolumn{5}{|l|}{ Spesific budget for PMTCT } \\
\hline No & $356(93.0)$ & $16(88.9)$ & $375(92.8)$ & 0.287 \\
\hline Yes & $27(7.0)$ & $2(11.1)$ & $29(7.2)$ & \\
\hline \multicolumn{5}{|l|}{$\begin{array}{l}\text { Availability of media for } \\
\text { PMTCT information }\end{array}$} \\
\hline No & $200(51.8)$ & $14(77.8)$ & $214(53.0)$ & 0.026 \\
\hline Yes & $186(48.2)$ & $4(22.2)$ & $190(47.0)$ & \\
\hline \multicolumn{5}{|c|}{ Had ever served HIV (+) patient } \\
\hline No & $246(70.5)$ & $55(100.0)$ & $301(74.5)$ & 0.000 \\
\hline Yes & $103(29.5)$ & $0(0.0)$ & $103(25.5)$ & \\
\hline \multicolumn{5}{|l|}{ Number of PMTCT patient } \\
\hline 0 & $75(21.5)$ & $20(36.4)$ & $95(23.5)$ & 0.019 \\
\hline $1-36$ & $246(70.5)$ & $34(61.8)$ & $280(69.3)$ & \\
\hline$>36$ & $28(8.0)$ & $1(1.8)$ & $29(7.2)$ & \\
\hline
\end{tabular}

Table 5. Role of PPM in PMTCT prong 1 based on their level of knowledge and attitude

\begin{tabular}{lcccc}
\hline \multirow{2}{*}{ Variable } & \multicolumn{2}{c}{ Role of PPM in PMTCT prong 1 } & & (\%) \\
\cline { 2 - 3 } & $\begin{array}{c}\text { Good } \\
\mathbf{n}(\%)\end{array}$ & $\begin{array}{c}\text { Lacking } \\
\mathbf{n}(\%)\end{array}$ & $\mathbf{n}$ \\
\hline Level of knowledge & & & & \\
Lacking & $44(11.4)$ & $2(11.1)$ & $46(11.4)$ & 0.970 \\
Good & $342(88.6)$ & $16(88.9)$ & $358(88.6)$ & \\
Level of attitude & $11(2.8)$ & & & \\
Lacking & $375(97.2)$ & $17(9.6)$ & $12(3.0)$ & 0.552 \\
Good & & & $392(97.0)$ & \\
\hline
\end{tabular}

counselling for HIV positive babies, counselling to families of HIV positive patients, and providing psychosocial support as well as medical support and care for HIV positive mothers. The PPM have performed their roles in prong 2,3 and 4 for HIV positive women well.

We found no significant association between the PPM characteristics, resources, knowledge and attitudes in general to their role in PMTCT for preventing HIV transmission in women of reproductive age (prong 1 PMTCT). Statistically significant associations to PMTCT role in prong 1 were found only for availability of information media, the experience of providing care for HIV positive patients, and the number of PMTCT patients who have been served. Most of the PPM that have a good role have information media in the form of brochures, leaflets and flipcharts about PMTCT. Thus, it is important to increase the availability of these information medias for patients in the PPM practice area, which in this case can be undertaken by PPM themselves or with assistance from the health office and from the midwife's associations. Information about PMTCT can also be provided when the Midwifery Update activities are held every year.

In addition, PPM who had ever cared for HIV positive patients and who had a higher number of PMTCT patients tend to have a better role which is reasonable due to more experiences. In this regard, it is important to increase the readiness of PPM to serve PMTCT patients, both by increasing training on PMTCT and providing a special budget for PMTCT, considering that training and special PMTCT budgets at PPM level are generally still quite low. Training activities on PMTCT can be carried out by the health office and the Indonesian Midwife Association, while budget provision is the responsibility of the health office of the PPM practice area/district. This will greatly determine the success of the PMTCT program in the future with the main objective of reducing mother-to-child transmission of HIV and controlling HIV cases in general.

No previous studies on PMTCT have specifically examined the role of midwives who performed private practice in these parts of PMTCT prongs. In a study in Yogyakarta, for example, it was found that the role of midwives was in the good category in PMTCT, but the respondents were taken from midwives practicing at the PHCs only and not based on the role of each of the prong. ${ }^{15}$ The assessment of the midwives role was not differentiated between those who have served HIV-positive patients (did all prong) and who have never served HIV-positive patients (only did PMTCT prong 1). Study in South Africa in 2016, found that the implementation of 
the role of health workers (doctors, midwives and nurses) was still low. ${ }^{16}$ The research was neither specifically carried out on PPM so it is possible that their role is not as good as that of midwives who are closer to PMTCT activities in their daily practice. In Bojonegoro (East Java), the PMTCT program was only carried out for prong 3 and 4 , while prong 1 and 2 had not been implemented because patients who visited the integrated PMTCT service in $\mathrm{MCH}$ services were only pregnant women. In this setting, only pregnant women were given information on PMTCT and HIV testing and it only included pregnant women who are at risk. This study took different respondents because it was only conducted on midwives in the setting of public local hospital (RSUD). ${ }^{17}$

The number of responses included in this study is quite good because in an online survey, the response rate is generally low or less than $20 \%^{18}$, while in our study it was $23 \%$. The response from each Indonesian Midwifery association branch in some districts such as in Badung, Buleleng and Tabanan were proportional to the size of PPM number in the area, but in several other districts such as Denpasar City, Karangasem District and Bangli the response was low, so the generalization of the result into the population of PPM in Bali should be performed with caution. Efforts to increase the response rate have been made, such as following up after the questionnaire was distributed, among others by calling and contacting the head of the midwife's associations branch via message service, but in some areas the results were not optimal.

Another limitation of this study is the possibility of a selection bias, in which only certain midwives provide responses. PPM who are interested and willing to fill out responses to this questionnaire may be those who have implemented PMTCT in their practice and have good knowledge and experience in PMTCT. Another weakness of this study is that the use of online questionnaires is strongly influenced by the level of honesty of the respondents. The process of filling out the questionnaire, which was carried out independently without face to face interview, also made it more difficult for researchers to evaluate the quality of the respondents' answers.

\section{CONCLUSION}

As many as $95.5 \%$ of 440 private practicing midwives (PPM) surveyed in Bali Province played a good role in prong 1 of PMTCT, and 99.0\% of PPM who had ever served HIV (+) patients played a good role in prong 2,3 and 4. Good role in prong 1 of PMTCT is significantly associated with the availability of information media, having served HIV positive women and the number of PMTCT patients who have been served. Hence, it is recommended to increase the availability of information media in the PPM practice area for patients, special training on PMTCT, and providing a budget for implementing PMTCT to increase the PPM involvement in the provision of PMTCT care.

\section{ACKNOWLEDGEMENTS}

We would like to thank all parties who have made this research possible, especially for the Public Health Postgraduate Program, Faculty of Medicine, Udayana University. We also thank Indonesian Midwives Association Branches in all districts/ cities in Bali Province and their members who were willing to participate in this research.

\section{AUTHOR CONTRIBUTION}

DP designed and compiled the literature for the study, collected and analysed the data, wrote and edited the manuscript. PPJ was involved in the design and conception of the study, providing feedback and input on improving the manuscript. DK provided feedback on the manuscript and provided expertise and input on statistical data analysis.

\section{CONFLICT OF INTEREST STATEMENT}

The authors declare no conflict of interest in this study.

\section{FUNDING}

DP received a scholarship for Masters studies from the Badung District government.

\section{REFERENCES}

1. World Health Organization. HIV/AIDS Key facts [Internet]. WHO. 2019 [cited 2019 Jul 17]. p. 1-9. Available from: https://www.who.int/news-room/fact-sheets/detail/ hiv-aids

2. UNAIDS. Global HIV \& AIDS statistics - 2019 fact sheet [Internet]. UNAIDS. 2019 [cited 2019 Jul 20]. p. 1-9. Available from: https://www.unaids.org/sites/default/files/ media_asset/2019-UNAIDS-data_en.pdf

3. John-Stewart G, Peeling RW, Levin C, Garcia PJ, Mabey D, Kinuthia J. Prevention of Mother-to-Child Transmission of HIV and Syphilis. Disease Control Priorities, Third Edition (Volume 6): Major Infectious Diseases. 2017. 113-136 p.

4. Ngwende S, Gombe NT, Midzi S, Tshimanga M, Shambira G. Factors associated with HIV infection among children born to mothers on the prevention of mother to child transmission programme at Chitungwiza Hospital , Zimbabwe. BMC Public Health. 2013; 13:1181.

5. World Health Organization. HIV/AIDS mother-to-child transmission of HIV. [Internet]. WHO. 2020 [cited 2020 Jun 11] 2020; 2014-5. Available from: https://www.who. int/hiv/topics/mtct/about/en/ 
6. AVERT. Prevention of mother-to-child transmission (PMTCT) of HIV [Internet]. 2018 [cited 2019 Aug 20]. Available from: https://www.avert. org/professionals/hivprogramming/prevention/prevention-mother-child

7. The Ministry of Health of the Republic of Indonesia. General situation of HIV/AIDS and HIV test. [Internet]. The Ministry of Health of the Republic of Indonesia. 2018 [cited 2019 Jun 30]. https://pusdatin.kemkes.go.id/article/ view/19042200004/situasi-umum-hiv-aids-dan-tes-hiv. html

8. Bali Provincial Health Office. Profil Kesehatan Provinsi Bali Tahun 2017. [The 2017 Bali Province Health Profile] [Internet]. 2017. [cited 2019 Sep 10]. Available from: http://www.diskes.baliprov.go.id/files/subdomain/ diskes/ ProfilKesehatanProvinsi Bali/Tahun 2015/Bali_Profil_2015. pdf

9. The Ministry of Health of the Republic of Indonesia. Pedoman Manajemen PPIA [The Guidelines of Mother-ToChild-Transmission Management]. The Ministry of Health of the Republic of Indonesia. Jakarta; 2015. 43 p.

10. Wulandari LPL, Lubis DSM, Widarini P, Widyanthini DN, Wirawan IMA, Wirawan DN. HIV testing uptake among pregnant women who attending private midwife clinics: challenges of scaling up universal HIV testing at the private sectors in Indonesia. Int $J$ Health Plann Manage. 2019;34(4):1399-1407.

11. UNICEF. Kesehatan Ibu \& Anak [Mother and Child Health]. UNICEF Indonesia [Internet]. 2012; (Gambar 2):1-2. Available from: http://www.unicef.org/indonesia/id/ A5_-_B_Ringkasan_Kajian_Kesehatan_REV.pdf

12. Widiastuti NMR, Adnyani NWS. The implementation of prevention of mother-to-children HIV transmission program by private midwife practice at Denpasar City. Int $J$ Res Med Sci. 2018;7(1):121.

13. Rowan BH, Robinson J, Granato A, Bla CK, Kouyaté S, Djety GV, et al. Workforce patterns in the prevention of mother to child transmission of HIV in Côte d'Ivoire: A qualitative model. Hum Resour Health. 2018;16(1):1-9.

14. The Elizabeth Glaser Pediatric Aids Foundation (EGPAF). Mother-To-Child Transmission of HIV Services in Lesotho. 2013.

15. Meilani N, Setiyawati N, Barasa SO. Midwife's Role in the Mother-to-Child Transmission Prevention Program in Primary Health Care in Yogyakarta. Natl Public Heal J. 2019;14(2):88-94.

16. Ogbonna K, Govender I, Tumbo J. Knowledge and practice of the prevention of mother-to-child transmission of HIV guidelines amongst doctors and nurses at Odi Hospital, Tshwane District. South African Fam Pract. 2016;58(5).

17. Erliana N, Suryoputro A, Mustofa SB. Gambaran Pelaksanaan Prevention Mother to Child Transmission di RSUD Kelas B Dr. R. Sosodoro Djatikoesoemo Kabupaten Bojonegoro [The description on Prevention of Mother to Child Transmission Program at Class B Dr. R. Sosodoro Djatikoesoemo District Hospital, Bojonegoro]. J Promosi Kesehat Indones. 2018;11(2):1.

18. Yuliansyah. Meningkatkan Response Rate pada Penelitian Survey-Suatu Study Literature [Increasing response rate in a survey study - a literature study]. Change Publisher. Edisi I. Jakarta. 2016

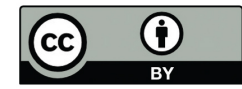

This work is licensed under a Creative Commons Attribution 